\title{
Positive health behaviours of students of Lublin universities and their selected determinants
}

\section{Pozytywne zachowania zdrowotne studentów lubelskich uczelni i ich wybrane uwarunkowania}

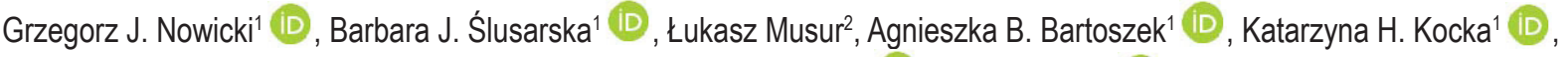 \\ Zdzisława C. Szadowska-Szlachetka ${ }^{3}$ (iD), Marta Łuczyk ${ }^{3}$ \\ ${ }^{1}$ Derartment of Family Medicine and Community Nursing, Faculty of Health Sciences, Medical University of Lublin \\ 2Urology Department, Independent Public Provincial Hospital John of Godin Lublin \\ ${ }^{3}$ Department of Oncology, Chair of Oncology and Environmental Health, Faculty of Health Sciences, \\ Medical University of Lublin
}

\begin{abstract}
INTRODUCTION: According to modern knowledge, we distinguish many factors conditioning human health. Among them, the most important is lifestyle. During the university education period, the first independent attempts and decisions are made, not only those related to life choices, but also decisions related to health behaviours that will have a consequence in adult life. The aim of the study was to assess the positive health behaviours among students of Lublin universities and their selected determinants.

MATERIAL AND METHODS: The study was conducted using the PAPI method from March to May 2017 among 410 male students. The study employed the Positive Health Behaviour Scale (PHBS) for adults and sociodemographic questions. The results of the study were subjected to statistical analysis.

RESULTS: The obtained results of the study carried out among students using PHBS allowed the authors to state that the respondents obtained the highest result in Subscale IV. "Safety" (2.46 \pm 0.59$)$, subsequently in Subscale III. "Relaxation and behaviours connected with psychosocial health" $(1.67 \pm 0.53)$. The lowest rated subscale was Subscale I. "Nutrition" (1.28 \pm 0.52$)$. Statistical analysis showed that age, the place of residence, place of residence during studies, field of studies, occurrence of cancer in the family and self-assessment of health condition determines the assessment of positive health behaviours $(\mathrm{p}<0.05)$.

CONCLUSIONS: The ranking of positive health behaviours among male students of Lublin universities is as follows: "Safety", "Relaxation and behaviours connected with psychosocial health", "Physical activity", "Taking care of one's body" and "Nutrition".
\end{abstract}

\section{KEY WORDS}

health behaviours, students, lifestyle, determinants, male gender

Received: $16.07 .2018 \quad$ Revised: $26.07 .2018 \quad$ Accepted: $19.11 .2019 \quad$ Published online: 13.08 .2020
Address for correspondence: Dr n. o zdr. Grzegorz J. Nowicki, Zakład Medycyny Rodzinnej i Pielęgniarstwa Środowiskowego, Wydział Nauk o Zdrowiu,
Uniwersytet Medyczny w Lublinie, ul. Staszica 4-6, 20-081, Lublin, Polska, tel. +48 81448 6810, e-mail: grzesiek_nowicki@interia.pl
Copyright @ Śląski Uniwersytet Medyczny w Katowicach
www.annales.sum.edu.pl




\section{STRESZCZENIE}

WSTĘP: Zgodnie ze współczesną wiedzą wyróżniamy wiele czynników warunkujących zdrowie człowieka. Wśród nich najważniejszy to styl życia. W okresie nauki na uczelni wyższej podejmowane są pierwsze samodzielne próby i decyzje, nie tylko te związane z wyborami życiowymi, ale także decyzje związane z zachowaniami zdrowotnymi, które będą miały konsekwencję w dorosłym życiu. Celem pracy była ocena pozytywnych zachowań zdrowotnych wśród studentów lubelskich uczelni oraz ich wybranych uwarunkowań.

MATERIA I METODY: Badania przeprowadzono metodą PAPI w okresie od marca do maja 2017 roku wśród 410 studentów płci męskiej. W badaniach wykorzystano Skalę Pozytywnych Zachowań Zdrowotnych dla dorosłych (SPZZ) oraz pytania metryczkowe. Wyniki badań poddano analizie statystycznej.

WYNIKI: Uzyskane wyniki badań wśród studentów ocenione na podstawie SPZZ pozwalają stwierdzić, że ankietowani uzyskali najwyższy wynik w subskali IV „Zachowanie bezpieczeństwa” $(2,46 \pm 0,59)$, następnie w subskali III „Sen, odpoczynek i zdrowie psychiczne” (1,67 $\pm 0,53)$. Najniżej oceniono subskalę I „Żywienie” $(1,28 \pm 0,52)$. Przeprowadzona analiza statystyczna wykazała, że wiek, miejsce stałego zamieszkania, miejsce zamieszkania podczas studiów, kierunek studiów, występowanie nowotworów w rodzinie oraz samoocena stanu zdrowia determinują ocenę pozytywnych zachowań zdrowotnych $(\mathrm{p}<0,05)$.

WNIOSKI: Ranking pozytywnych zachowań zdrowotnych wśród studentów płci męskiej lubelskich uczelni kształtuje się następująco: „Zachowanie bezpieczeństwa”, „Sen, odpoczynek i zdrowie psychiczne”, „Aktywność fizyczna”, „Dbałość o ciało” oraz „Żywienie”.

\section{SŁOWA KLUCZOWE}

zachowania zdrowotne, studenci, styl życia, determinanty, płeć męska

\section{INTRODUCTION}

Health behaviours concern all human activities that directly or indirectly influence their health and well-being, which also constitute the main category of lifestyle and are in the area of interest mainly in education and health promotion. Among health behaviours, behaviours that affect health positively (pro-healthy) and those that affect health negatively (anti-healthy) are distinguished [1]. Health education aims to form proper habits and attitudes conductive to health [2]. Human health behaviours form already in early childhood, in the process of socialisation. The factors influencing the forming of a given behaviour are, among others, role models at home, kindergarten, school, local community, mass media, advertisements, etc. [3]. Nowadays, studying health behaviours is considered an important method of measuring the population's health status in terms of prevention. It is also a base for planning and evaluating health education, developing prevention programmes and health promotion projects.

Health behaviours and their determinants are in the centre of interest of many social and medical studies. Despite the differences in the scope of research methods, scientific purposes and traditions, individual scientific disciplines focus their research on man, his behaviours and living environment. Thanks to empirical analyses of health behaviours and their determinants through the prism of different scientific disciplines, resulting from their different scientific workshops and experience, the study results and theoretical considerations bring new light into the multi-dimensional view on this issue.

According to current knowledge, we distinguish many factors determining human health. Among them, the most important are lifestyle which determines health

\section{WSTEP}

Zachowania zdrowotne dotyczą wszystkich działań człowieka, które pośrednio i bezpośrednio wpływają na jego zdrowie oraz samopoczucie. Stanowią główną kategorię stylu życia i znajdują się w obszarze zainteresowań głównie edukacji oraz promocji zdrowia. Wśród zachowań zdrowotnych wyróżnia się wpływające pozytywnie na zdrowie (prozdrowotne) oraz szkodliwe (antyzdrowotne) [1]. Celem wychowania zdrowotnego jest ukształtowanie właściwych nawyków i postaw sprzyjających zdrowiu [2]. Zachowania zdrowotne człowieka kształtują się już we wczesnym dzieciństwie, w procesie socjalizacji. Czynnikami wpływającymi na kształtowanie danego zachowania są m.in. wzorce osobowe w domu, przedszkolu, szkole, społeczności lokalnej, mass mediach, reklamach itd. [3]. W obecnych czasach badanie zachowań zdrowotnych jest uważane za ważną metodę pomiaru stanu zdrowia populacji w perspektywie prewencyjnej, stanowiącą także podstawę planowania i ewaluacji edukacji zdrowotnej, opracowywania programów profilaktycznych oraz projektów promocji zdrowia.

Zachowania zdrowotne i ich determinanty stanowią centrum zainteresowania wielu dyscyplin nauk społecznych i medycznych. Pomimo różnych metod badań, celów i tradycji naukowych, poszczególne dyscypliny naukowe ogniskują swoje badania na człowieku, jego zachowaniach i środowisku życia. Dzięki empirycznym analizom zachowań zdrowotnych i ich uwarunkowań dokonywanym przez pryzmat różnych dyscyplin naukowych, co wiąże się z odrębnym warsztatem naukowym i doświadczeniami danej dyscypliny, wyniki badań i rozważania teoretyczne wnoszą nowe światło w wielowymiarowe postrzeganie tego zagadnienia. 
about 53\%, next the macro- and microenvironment of living $-21 \%$, human biology, i.e. the inherited genetic code $-16 \%$ and the organisation of healthcare $-10 \%$. The listed factors are presented in M. Lalonde's concept of health fields. This system should be complemented by noting the role of human lifestyle and environment in determining health. The healthy lifestyle of a modern human consists mainly of such elements as physical activity, healthy diet, the manner of spending free time, proper relationships at work, the ability to manage stress, abstinent behaviours, getting rid of conflict and aggression when dealing with others and overall life optimism [4].

In the general population, gender differentiates the approach to and realisation of pro-healthy behaviours. On the basis of numerous study results, a conclusion may be made that women represent a more pro-healthy lifestyle than men, e.g. in terms of pro-healthy diet preferences [5], not-smoking [6] or a lower cardiovascular risk in the SCORE scale [7]. Gender, as a variable that differentiates health concerning behaviours, is taken into account in many research analyses, although only from the feminist perspective it is assumed as the main axis of analysis. Assuming gender is one of the important determinants of inequalities in health status and health behaviours, two types of dependencies should be noted: a differentiation between women and men resulting from biological factors and this caused by socio-cultural factors $[8,9]$. The research results presented in this paper will be an attempt to analyse health behaviours in a group of men from the perspective of positive determinants. It is an analysis of the material gathered in the first stage of the research. Therefore, this study aims to assess positive health behaviours among male students of Lublin universities and their chosen determinants (age, place of residence, place of temporary residence during studies, major, material status, occurrence of cancer in the family and self-estimation of a health status). The first proposed hypothesis is: among positive health behaviours in a group of male students, those in terms of safety will be the highest-rated and those involving diet - the lowest-rated. The second hypothesis stated that age, place of residence, place of temporary residence during studies, major, material status, the occurrence of cancer in the family and the self-estimation of health status differentiate the evaluation of positive health behaviours.

\section{MATERIAL AND METHODS}

\section{Study sample}

The study involved 480 male students of five Lublin higher educational institutions at the age of $18-28$
Zgodnie ze współczesną wiedzą wyróżniamy wiele czynników warunkujących zdrowie człowieka. Wśród nich najważniejsze to: styl życia, który determinuje zdrowie w około 53\%, następnie makro- i mikrośrodowisko życia (21\%), biologia człowieka, czyli dziedziczony kod genetyczny (16\%), oraz organizacja opieki zdrowotnej (10\%). Wymienione czynniki przedstawione są w koncepcji pól zdrowia M. Lalonde’a. Uzupełnieniem tego systemu jest zwrócenie uwagi na rolę stylu życia i środowiska człowieka w uwarunkowaniu zdrowia. Na zdrowy styl życia współczesnego człowieka składają się przede wszystkim takie elementy, jak: aktywność fizyczna, właściwe odżywianie, sposób spędzania wolnego czasu, odpowiednie relacje w pracy, umiejętność opanowania stresu, zachowania abstynenckie, pozbycie się konfliktowości i agresji w kontaktach z innymi oraz optymizm życiowy [4].

W populacji ogólnej płeć różnicuje podejście i realizację zachowań prozdrowotnych. Na podstawie wielu wyników badań można wysnuć wniosek, że kobiety reprezentują bardziej prozdrowotny styl życia niż mężczyźni np. w zakresie prozdrowotnych preferencji żywieniowych [5], niepalenia papierosów [6] czy niższego ryzyka sercowo-naczyniowego w skali SCORE [7]. Płeć, jako zmienna różnicująca zachowania związane ze zdrowiem, brana jest pod uwagę w wielu analizach badawczych, choć jedynie z perspektywy feministycznej przyjmuje się ją za główną oś analizy. Uznając płeć za jeden z istotnych wyznaczników nierówności w stanie zdrowia i zachowaniach zdrowotnych, zwrócić uwagę należy na dwa typy zależności, tj. zróżnicowanie pomiędzy kobietami i mężczyznami wynikające z przyczyn biologicznych oraz społeczno-kulturowych $[8,9]$. Prezentowane w pracy wyniki badań będą stanowić próbę analizy z perspektywy pozytywnych uwarunkowań zachowań zdrowotnych w grupie mężczyzn. Jest to analiza materiału zebranego podczas pierwszego etapu badań. Celem tego badania była ocena pozytywnych zachowań zdrowotnych wśród studentów płci męskiej lubelskich uczelni oraz ich wybranych uwarunkowań (wiek, miejsce stałego zamieszkania, miejsce zamieszkania podczas studiów, kierunek studiów, status materialny, występowanie nowotworów w rodzinie oraz samoocena stanu zdrowia). Pierwsza hipoteza, jaką postawiliśmy, brzmiała następująco: spośród pozytywnych zachowań zdrowotnych najwyżej ocenianymi w grupie studentów płci męskiej będą zachowania w zakresie bezpieczeństwa, a najniżej zachowania związane ze sposobem żywienia. Druga hipoteza mówiła, że wiek, miejsce zamieszkania, miejsce zamieszkania podczas studiów, kierunek studiów, status materialny, występowanie choroby nowotworowej w rodzinie oraz samoocena stanu zdrowia respondentów istotnie różnicują ocenę pozytywnych zachowań zdrowotnych. 
(Fig. 1). The representative sample size for this age category was calculated using the Dobson formula [10]. From the studied group of 480 people, the optimal group was chosen by the method of stratified sampling, adequate in structure to the parameters such as age and gender, determining thus the final group of 410 persons. A PAPI (paper and pencil interview) was held from March to May 2017. The study was voluntary and anonymous. Each respondent was orally informed on the aim of the study and the way of filling in the questionnaires, then oral consent to participate in the study was obtained. The scientific procedure was conducted in accordance with the Declaration of Helsinki.

\section{Tools}

\section{Sociodemographic data}

The respondents were asked to indicate their age, then they were divided into groups of persons at the age of 20 and less, 21, 22 and more. The next question concerned the place of permanent residence ("village" or "town") and place of temporary residence during studies ("family home", "with family", "residence hall" or "lodgings"). The participants were asked to indicate their faculty of studies, which were then classified as: medical ("nursing", "emergency medical rescue", "biotechnology", "medicine", "pharmacy") and non-medical ("English studies", "Slavic studies", "construction engineering", "IT", "sociology", "psychology" or "theology"). In the next questions, the respondents were asked to determine their material status ("poor", "average", "good" or "very good"), the occurrence of cancer in the family ("yes" or "no") and the assessment of their health status ("poor", "average", "good" or "very good").

\section{Positive Health Behaviours Scale (PHBS) for adults}

Positive Health Behaviours Scale for adults (PHBS), according to M. Woynarowska-Sołdan and K. Hildt-Ciupińska, is a tool consisting of 32 statements, divided into 5 subscales [11]:

- I. "Diet" - concerns mainly the right eating habits; this research instrument assesses the regularity of meals, consumption of fruits and vegetables, reduction of vegetable fats, salt and sweets.

- II. "Body care" - covers prophylactic behaviours concerning following health recommendations, e.g. dressing adequately to the weather, daily tooth brushing, performing preventive examinations and obtaining information on health and disease.

- III. "Sleep, rest and mental health" - concerns the number of hours which the respondents devote to sleep and rest, how they manage stress and strong emotions.

- IV. "Ensuring safety" - covers the behaviours concerning e.g. driving, following traffic rules and using electrical equipment correctly.

- V. "Physical activity" - covers behaviours involving time devoted to physical exertion.

\section{MATERIA I METODY}

\section{Badana próba}

W badaniu wzięło udział 480 studentów płci męskiej w wieku 18-28 lat pięciu lubelskich uczelni wyższych (ryc. 1). Wielkość reprezentatywnej próby dla tej kategorii wiekowej obliczono przy użyciu wzoru Dobson [10]. Z przebadanych 480 osób wyodrębniono metodą próbkowania warstwowego (stratyfikacyjnego) optymalną grupę strukturalnie adekwatną pod względem wieku i płci, uzyskując finalnie grupę 410 osób. Dobrowolne $\mathrm{i}$ anonimowe badania zostały przeprowadzone metodą PAPI (paper and pencil interview) w okresie od marca do maja 2017 roku. Każdy respondent został poinformowany ustnie o celu badania oraz sposobie wypełniania kwestionariuszy, następnie wyrażał ustną zgodę na udział w badaniu. Realizowana procedura badawcza była zgodna z Deklaracją Helsińską.

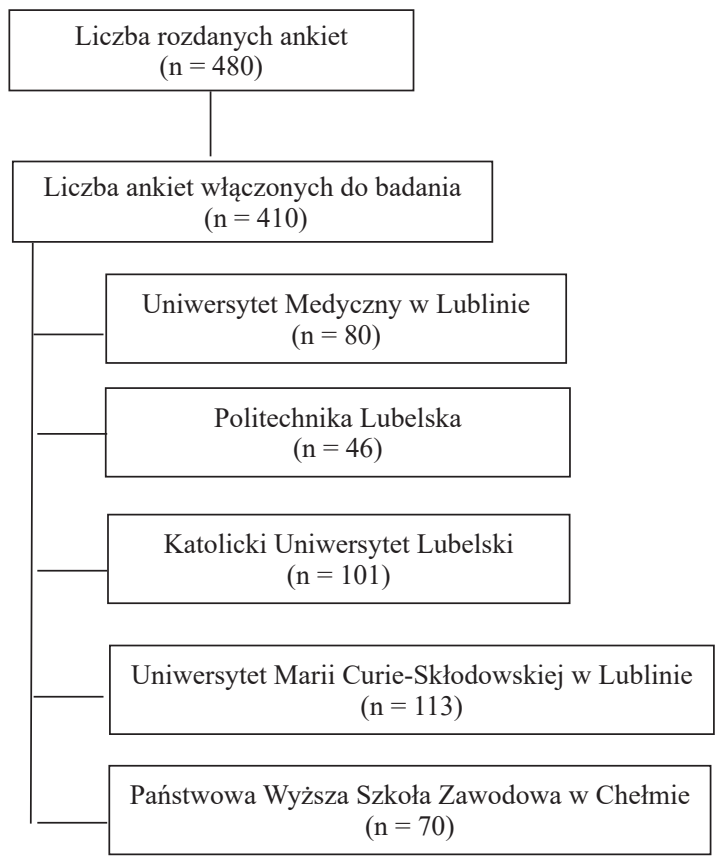

Fig. 1. Diagram showing method of selecting respondents. Ryc. 1. Schemat pokazujący metodę doboru badanej grupy.

\section{Narzędzia}

Dane socjodemograficzne

Respondentów poproszono o wskazanie wieku, a następnie podzielono ich na grupy 20 lat i mniej, 21 lat oraz 22 lata i więcej. Kolejne pytanie dotyczyło stałego miejsca zamieszkania („wieś” i „miasto”) oraz miejsca zamieszkania podczas studiów (,dom rodzinny”, „,u rodziny”, ,akademik” lub „stancja”). Uczestnicy zostali poproszeni o wskazanie kierunku studiów, które następnie sklasyfikowano jako: medyczne (,,pielęgniarstwo”, „ratownictwo medyczne”, ,biotechnologia”, „lekarski”, „farmacja”) i niemedyczne (,filologia angielska”, „,filologia słowiańska”, ,budownictwo”, „,informa- 
The respondents assessed the frequency of a given behaviour on a 4-point scale: always or almost always, often, sometimes, never, or almost never. Each subscale result was computed by summing up the point values of the answers selected by the respondents: the higher point average, the higher value of a given scale.

\section{Methods of statistical analyses}

Questionnaire-based survey research was ordered, then codified according to the adequately developed categories and transferred to an Excel Microsoft Office spreadsheet. The grouped material was statistically analysed in order to perform full and detailed characterisation. The values of the analysed, the quantitative parameters were presented by means of mean, median, minimum, and maximum values, lower and upper quartile and standard deviation, and the qualitative parameters by means of cardinality and percentage.

The normality of the distribution of variables was verified using the Shapiro-Wilk test. To examine the differences between the two groups, Student's t-test was used, and in the case of not meeting the demands of using it - the nonparametric Mann-Whitney U test was applied. Comparison of the three groups was conducted using ANOVA and in the case of not meeting the requirements of using it - the nonparametric Kruskal-Wallis test was applied. The significance level was established as $\mathrm{p}<0.05$. The database and statistical data were developed based on Statistica 9.1 software (StatSoft, Poland).

\section{RESULTS}

\section{Characteristics of surveyed students}

The study involved 410 male students of Lublin universities, at the age of 18 to 28 . The average age of the studied group was $21.24 \pm 1.43$ years old. The largest group was constituted by persons at the age of 22 and above $-36.01 \%(n=148)$. Most of the students were inhabitants of rural areas $-51.22 \%(n=210)$. Most of the respondents indicated lodgings as their place of residence during studies $(44.39 \% ; \mathrm{n}=182)$. The respondents studying at non-medical faculties constituted $80.49 \%(n=330)$ of the tested group. Other sociodemographic factors are presented in Table I.

Table I. Sociodemographic characteristics of respondents
Tabela I. Charakterystyka socjodemograficzna badanych
\begin{tabular}{cc}
\multicolumn{1}{c}{ Variable/Zmienna } & $\mathbf{n}(\%)$ \\
\hline 1 & 2 \\
\hline Age/Wiek & $124(30.24 \%)$ \\
$\geq 20$ years/ $\geq 20$ lat & $138(33.66 \%)$ \\
21 years/21 lat & $148(36.1 \%)$ \\
$\leq 22$ years/ $\leq 22$ lata
\end{tabular}

tyka”, „socjologia”, ,psychologia”, „teologia”). W kolejnych pytaniach respondentów poproszono o określenie swojego statusu materialnego (,zły”, ,przeciętny”, „,dobry”, „,bardzo dobry”), występowanie nowotworów w najbliższej rodzinie (,tak”, „nie”) oraz ocenę stanu zdrowia (,zły”, ,średni”, ,dobry”, ,bardzo dobry”).

\section{Skala Pozytywnych Zachowań Zdrowotnych (SPZZ) dla dorostych}

Skala Pozytywnych Zachowań Zdrowotnych dla dorosłych (SPZZ) wg M. Woynarowskiej-Sołdan i K. Hildt-Ciupińskiej to narzędzie składające się z 32 stwierdzeń, pogrupowanych w pięć subskal [11]:

- I. „Żywienie” - dotyczy ona prawidłowych nawyków żywieniowych; narzędzie badawcze ocenia: regularne spożywanie posiłków, spożywanie owoców i warzyw, ograniczanie tłuszczów roślinnych, soli i słodyczy.

- II. „Dbałość o ciało” - obejmuje zachowania profilaktyczne dotyczące przestrzegania zaleceń zdrowotnych, np. ubieranie się adekwatnie do pogody, codzienne mycie zębów, wykonywanie badań profilaktycznych, oraz uzyskiwania informacji na temat zdrowia i choroby.

- III. „Sen, odpoczynek i zdrowie psychiczne” - dotyczy liczby godzin, jaką badani poświęcają na sen i odpoczynek, w jaki sposób radzą sobie ze stresem i silnymi emocjami.

- IV. „Zachowanie bezpieczeństwa” - obejmuje zachowania dotyczące m.in. jazdy samochodem, przestrzegania przepisów ruchu drogowego i prawidłowego użytkowania urządzeń elektrycznych.

- V. „Aktywność fizyczna” - obejmuje zachowania dotyczące czasu poświęcanego na wysiłek fizyczny.

Częstość podejmowania danego zachowania badany określał w 4-punktowej skali: zawsze lub prawie zawsze, często, czasem, nigdy lub prawie nigdy. Wynik każdej z podskal obliczono, sumując wartości punktowe zaznaczone przez respondentów; im wyższa średnia punktów, tym wyższa wartość danej skali.

\section{Metody analiz statystycznych}

Przeprowadzone na podstawie kwestionariusza badania ankietowe zostały uporządkowane, a następnie poddane kodyfikacji według opracowanych odpowiednio kategorii i przeniesione do arkusza Excel Microsoft Office. Pogrupowany materiał poddano analizie statystycznej w celu dokonania pełnej i szczegółowej charakterystyki. Wartości analizowanych parametrów ilościowych przedstawiono za pomocą wartości średniej, mediany, wartości minimalnych i maksymalnych, dolnego i górnego kwartyla oraz odchylenia standardowego, a parametry jakościowe w postaci liczności i odsetka.

Normalność rozkładu zmiennych sprawdzono za pomocą testu Shapiro-Wilka. Do zbadania różnic pomiędzy dwiema grupami zastosowano test t-Studenta, a w przypadku niespełnienia wymogów do jego zastosowania - nieparametryczny test U Manna-Whitneya. 
cd. tab. I

\begin{tabular}{|c|c|}
\hline 1 & 2 \\
\hline \multicolumn{2}{|l|}{ Place of residence/ } \\
\hline town/miasto & $200(48.79 \%)$ \\
\hline village/wieś & $210(51.21 \%)$ \\
\hline \multicolumn{2}{|c|}{$\begin{array}{l}\text { Place of residence during studies/Miejsce zamieszkania podczas } \\
\text { studiów }\end{array}$} \\
\hline family home/dom rodzinny & $113(27.56 \%)$ \\
\hline with family/u rodziny & $14(3.41 \%)$ \\
\hline residence hall/akademik & $101(24.63 \%)$ \\
\hline lodgings/stancja & $182(44.39 \%)$ \\
\hline \multicolumn{2}{|l|}{ Major/Kierunek studiów } \\
\hline medical/medyczny & $80(19.51 \%)$ \\
\hline non-medical/niemedyczny & $330(80.49 \%)$ \\
\hline \multicolumn{2}{|l|}{ Material status/Status materialny } \\
\hline poor/zły & $5(1.22 \%)$ \\
\hline average/przeciętny & $99(24.15 \%)$ \\
\hline good/dobry & $235(57.32 \%)$ \\
\hline very good/bardzo dobry & $71(17.32 \%)$ \\
\hline \multicolumn{2}{|c|}{ Occurrence of cancer in family/Wstępowanie nowotworów w rodzinie } \\
\hline yes/tak & $147(35.85 \%)$ \\
\hline no/nie & $263(64.15 \%)$ \\
\hline \multicolumn{2}{|l|}{ Health status/Stan zdrowia } \\
\hline poor/zły & $4(0.98 \%)$ \\
\hline average/średni & $52(12.68 \%)$ \\
\hline good/dobry & $235(57.32 \%)$ \\
\hline very good/bardzo dobry & $119(29.02 \%)$ \\
\hline
\end{tabular}

Positive health behaviours and their chosen determinants

The obtained research results among the students conducted based on PHBS allow the authors to state that the respondents scored the highest result in Subscale IV "Ensuring safety" (2.46 \pm 0.59$)$, then in Subscale
Porównania trzech grup dokonano, wykorzystując analizę wariancji ANOVA, a w przypadku niespełnienia wymogów do jej zastosowania - nieparametryczny test Kruskala-Wallisa. Przyjęto poziom istotności $\mathrm{p}<0,05$. Bazę danych i badania statystyczne wykonane $\mathrm{z}$ wykorzystaniem oprogramowania komputerowego Statistica 9.1 (StatSoft, Polska).

\section{WYNIKI}

\section{Charakterystyka badanych studentów}

Badaniami objęto 410 studentów lubelskich uczelni, płci męskiej, w wieku od 18 do 28 roku życia. Średnia wieku badanej grupy wynosiła 21,24 $\pm 1,43$ lata. Najliczniejszą grupę stanowiły osoby w wieku 22 lata i powyżej - 36,01\% $(n=148)$. Większość studentów zamieszkiwało rejony wiejskie $-51,22 \%(n=210)$. Najwięcej respondentów jako miejsce zamieszkania podczas studiów wskazało stancję $(44,39 \% ; n=182)$. Respondenci studiujący na kierunkach niemedycznych stanowili 80,49\% $(\mathrm{n}=330)$ badanej grupy. Pozostałe cechy socjodemograficzne zostały przedstawione $\mathrm{w}$ tabeli I.

\section{Pozytywne zachowania zdrowotne i ich wybrane uwarunkowania}

Badanie przeprowadzone na podstawie SPZZ pozwala stwierdzić, że ankietowani uzyskali najwyższy wynik w subskali IV „Zachowanie bezpieczeństwa” (2,46 \pm 0,59), następnie w subskali III ,Sen, odpoczynek i zdrowie psychiczne" $(1,67 \pm 0,53)$. Nieco niższy wynik osiągnięto w subskali $V$ „Aktywność fizyczna” $(1,55 \pm 0,62)$ oraz II „Dbałość o ciało” $(1,43 \pm 0,55)$. Najniżej ocenio subskalę I „Żywienie” (1,28 $\pm 0,52)$. Szczegółowe dane przedstawia tabela II. Przeprowadzona analiza statystyczna wykazała, że wiek, miejsce stałego zamieszkania, miejsce zamieszkania podczas studiów, kierunek studiów, występowanie nowotworów w rodzinie oraz samoocena stanu zdrowia determinują ocenę pozytywnych zachowań zdrowotnych. Jedynie status material-

Table II. Positive health behaviours in the studied group of students Tabela II. Pozytywne zachowania zdrowotne w badanej grupie studentów

\begin{tabular}{|c|c|c|c|c|}
\hline Subscales/Podskale & $\mathrm{M} \pm \mathrm{SD}$ & $\begin{array}{l}\text { Median } \\
\text { Mediana }\end{array}$ & Min.-Maks. & Q1-Q3 \\
\hline I. Diet/Żywienie & $1.28 \pm 0.52$ & 1.22 & $0.11-3.00$ & $1.00-1.67$ \\
\hline II. Body care/Dbałość o ciało & $1.43 \pm 0.55$ & 1.37 & $0.25-3.00$ & $1.00-1.75$ \\
\hline $\begin{array}{l}\text { III. Sleep, rest and mental health/Sen, } \\
\text { odpoczynek i zdrowie psychiczne }\end{array}$ & $1.67 \pm 0.53$ & 1.71 & $0.14-3.00$ & $1.28-2.00$ \\
\hline $\begin{array}{l}\text { IV. Ensuring safety/Zachowanie } \\
\text { bezpieczeństwa }\end{array}$ & $2.46 \pm 0.59$ & 2.50 & $0.50-3.00$ & $2.00-3.00$ \\
\hline V. Physical activity/Aktywność fizyczna & $1.55 \pm 0.62$ & 1.50 & $0.25-3.00$ & $1.00-2.00$ \\
\hline
\end{tabular}

Key/Legenda:

M - mean, SD - standard deviation, Q1 - lower quartile, Q3 - upper quartile/M(mediana) - średnia, SD - odchylenie standardowe, Q1 - dolny kwartyl, Q3 - górny kwartyl 
III "Sleep, rest and mental health" (1.67 \pm 0.53$)$. A bit lower result was obtained in Subscale V "Physical activity" (1.55 \pm 0.62$)$ and Subscale II "Body care" (1.43 \pm $0.55)$. The lowest-rated subscale was Subscale I "Diet" $(1.28 \pm 0.52)$. The detailed data are presented in Table II. The carried out statistical analysis indicated that age, place of permanent residence, place of temporary residence during studies, major, the occurrence of cancer in the family and the self-estimation of health status determine the assessment of positive health behaviours. The material status was the only variable that did not differentiate the assessment on individual subscales in PHBS in the tested males $(\mathrm{p}>0.05)$. Detailed data are presented in Table III.

Variables such as age, major and the self-estimation of health state by the respondents were found to be the ones that significantly determined the assessment on Subscale I "Diet". The following variables: age, place of residence, place of residence during studies, major, the occurrence of cancer in the family and self-estimation of their health status by the respondents, significantly influenced the assessment of positive health behaviours on Subscale II "Body care". The place of residence during studies, major, the occurrence of cancer in the family and the self-estimation of their health status by the respondents were the variables that significantly influenced the assessment on Subscale III "Sleep, rest and mental health". Statistical analysis indicated that age and the occurrence of cancer in the family are the variables that significantly influence the assessment in Subscale IV "Ensuring security", whereas age, place of residence during studies, major, the occurrence of cancer in the family and the self-estimation of their health status by the respondents were found statistically significant for the variable determining physical activity, i.e. the assessment on Subscale V.

\section{DISCUSSION}

Deficiencies in pro-health behaviours contribute to the development of health disorders, not only in youth, but also in subsequent years of life [12]. Studying is a unique period of life. During university education, the first independent attempts and decisions are made - not only those related to life choices, but also those related to health behaviours, which will have consequences in adult life. The period of student independence and self-reliance favours many attempts to check, choose and change health behaviours. This is the time of searching for one's own solutions for health care and developing a health identity [13]. The students' lifestyle is determined by many factors, including the timetable of classes, exhaustion, distance of the university from the place of residence, place of residence during studies, as well as the habits formed in the family home. Academic youth should be aware of the impact of specific behaviour on health, know the role that proper lifestyle plays in maintaining and maximising health, especially since after graduation they will constitute an intellectual elite responsible for instilling pro-health behaviour in ny był zmienną, która nie różnicowała oceny w poszczególnych subskalach SPZZ badanych mężczyzn $(\mathrm{p}>0,05)$. Szczegółowe dane przedstawia tabela III. Zmiennymi istotnie determinującymi ocenę w subskali I „Żywienie” okazały się wiek, kierunek studiów oraz samoocena stanu zdrowia respondentów. Na ocenę pozytywnych zachowań zdrowotnych w subskali II „Dbałość o ciało" istotnie wpływały następujące zmienne: wiek, miejsce zamieszkania, miejsce zamieszkania podczas studiów, kierunek studiów, występowanie choroby nowotworowej $\mathrm{w}$ rodzinie oraz samoocena stanu zdrowia ankietowanych. Zmiennymi istotnie wpływającymi na ocenę w subskali III „Sen, odpoczynek i zdrowie psychiczne", były: miejsce zamieszkania podczas studiów, kierunek studiów, występowanie choroby nowotworowej w rodzinie oraz samoocena stanu zdrowia respondentów. Analiza statystyczna wykazała, że zmiennymi istotnie determinujące ocenę w subskali IV „Zachowanie bezpieczeństwa” są: wiek oraz występowanie choroby nowotworowej w rodzinie, natomiast dla zmiennej identyfikującej aktywność fizyczną czyli ocenę w subskali $\mathrm{V}$, istotne statystycznie okazały się wiek, miejsce zamieszkania podczas studiów, kierunek studiów, występowanie choroby nowotworowej w rodzinie oraz samoocena stanu zdrowia.

\section{DYSKUSJA}

Niedostatki zachowań prozdrowotnych przyczyniają się do powstania zaburzeń stanu zdrowia nie tylko w młodości, lecz także w kolejnych latach życia [12]. Studiowanie jest niepowtarzalnym w swojej specyfice okresem życia, kiedy podejmowane są pierwsze samodzielne próby i decyzje, nie tylko te związane $\mathrm{z}$ wyborami życiowymi, ale także związane $\mathrm{z}$ zachowaniami zdrowotnymi, które będą miały konsekwencję w dorosłym życiu. Czas studenckiej niezależności i samodzielności sprzyja wielu próbom sprawdzania, wybierania i zmieniania zachowań zdrowotnych. Jest to czas poszukiwania własnych rozwiązań mających na celu dbanie o zdrowie oraz budowania tożsamości zdrowotnej [13]. Styl życia studentów uwarunkowany jest wieloma czynnikami, spośród których należy wymienić: rozkład zajęć dydaktycznych, przemęczenie, lokalizację uczelni od miejsca zamieszkania, miejsce zamieszkania podczas studiów, ale także nawyki wyniesione $\mathrm{z}$ domu rodzinnego. Młodzież akademicka powinna być świadoma wpływu konkretnych zachowań na zdrowie, znać rolę, jaką odgrywa właściwy styl życia w utrzymaniu i pomnażaniu zdrowia, zwłaszcza, że po skończeniu studiów stanowić będzie elitę intelektualną, odpowiedzialną za zaszczepienie zachowań prozdrowotnych w młodszych pokoleniach [14]. Uzyskane wyniki badań potwierdziły hipotezę pierwszą, ponieważ w ocenie pozytywnych zachowań zdrowotnych najwyżej punktowana była subskala IV ,Zachowanie bezpieczeństwa", natomiast badani studenci, najniższą ocenę uzyskali w subskali I „Żywienie”. Druga postawiona przez nas hipoteza została częściowo potwierdzona, ponieważ w badanej grupie studentów na 

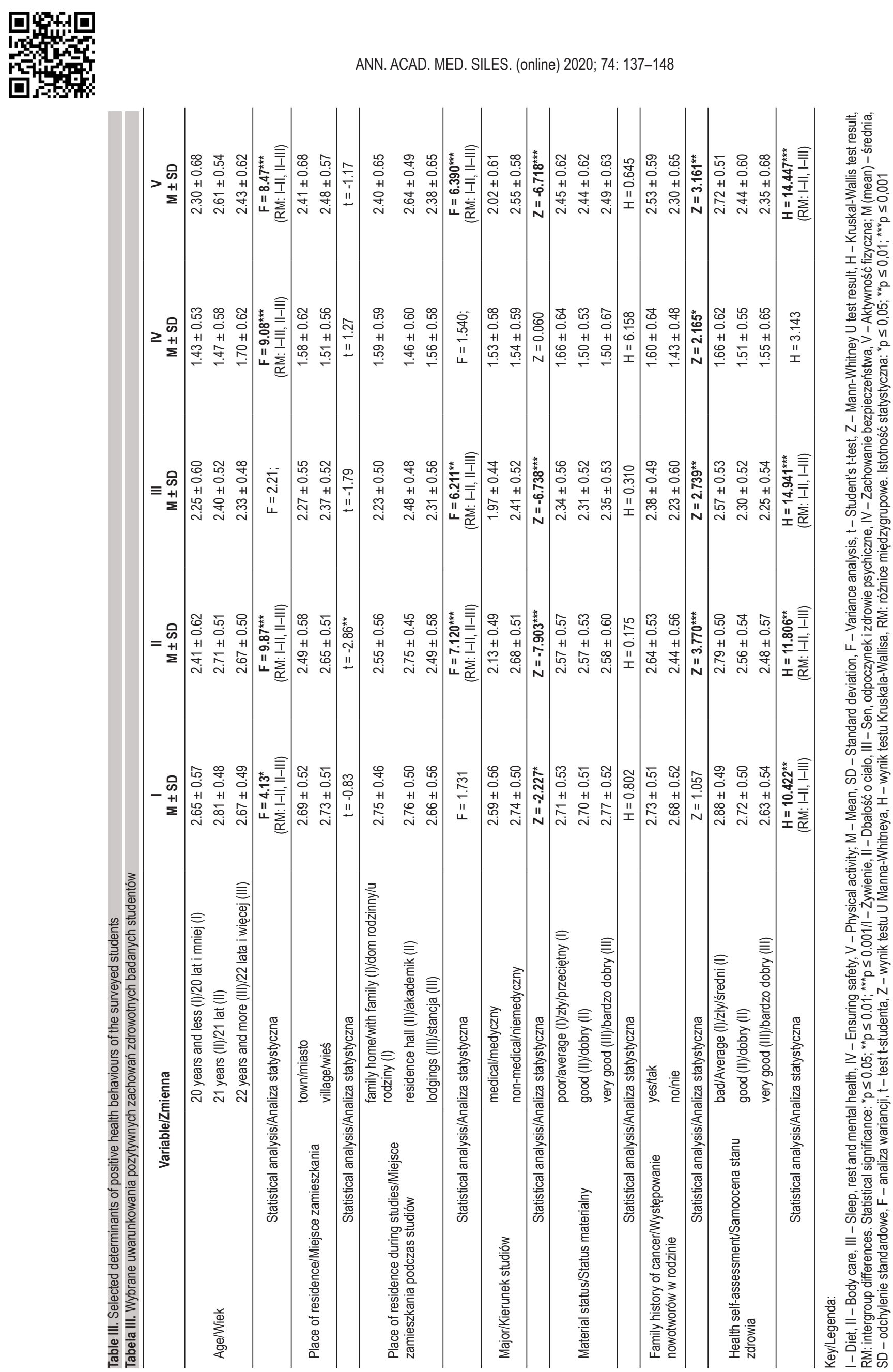
younger generations [14]. The study results confirmed the first hypothesis, as the highest-scoring subscale in the rating for positive health behaviours was Subscale IV - "Ensuring safety". The surveyed students scored the lowest rating in Subscale I "Diet". Our second hypothesis was partially confirmed - in the studied group of students, the level of assessment of positive health behaviours was not significantly affected by the self-assessment of material status in any of the subscales of the SPSS questionnaire; the remaining analysed variables significantly differentiated the rating for positive health behaviours.

Students are more likely to succumb to various temptations of daily life than adults. They are interested in new experiences, oriented to discovering what is forbidden as well as to satisfying their own cognitive curiosity. Therefore, they less frequently take into account their own safety, which is manifested by a greater tendency to reckless driving or alcohol and cigarette abuse. They also spend a great deal of time in front of the computer [15]. The research conducted by Zalewska-Puchała et al. [16], involving a group of 105 students, indicates that $70 \%$ of the respondents admits that they wear seatbelts when driving a car, but only $47 \%$ of the respondents wears a helmet when roller skating or cycling. According to Randak-Jeziorska's research [17], male students are more likely not to wear seat belts while driving. Kostecka's study [18], conducted in a group of 2465 students, showed that people with an abnormal BMI significantly more often spent their time in front of a computer. Our own research does not confirm the above-mentioned results. Among the surveyed students, the highest-rated positive health behaviour was ensuring safety. However, the factors determining the rating in this subscale included: age and a family history of cancer. The subscale assessed such types of behaviour as: fastening seat belts when driving a car, wearing a helmet when riding a bicycle, observing traffic regulations, maintaining safety by the water, as well as observing safety regulations when using electrical and mechanical equipment, chemicals and playing with fireworks.

The community still lacks awareness of the importance of sleep for human life and the consequences of not having enough sleep [19]. Sleep and mental health are closely linked. Sleep deprivation can cause many physical health problems. People disregard this issue, which may lead to health loss or even premature death due to undiagnosed and untreated sleep disorders [20]. In our study, positive health behaviours in terms of sleep, rest and mental health were ranked second. The research results conducted by Górska-Kłęk et al. [21], involving 185 students, showed that the majority of respondents slept 6-8 hours a day and more than half of them slept during the day. On the other hand, the survey by Błońska et al. [22], conducted among 600 students, showed that $48 \%$ of respondents had trouble falling asleep and $61 \%$ of respondents admitted that they did not wake up with more energy. Białkowska et al. [23] conducted research on mental health among 298 students (194 poziom oceny pozytywnych zachowań zdrowotnych w żadnej z subskal kwestionariusza SPZZ nie wpływała istotnie samoocena statusu materialnego, a pozostałe analizowane zmienne istotnie różnicowały ocenę pozytywnych zachowań zdrowotnych.

Studenci, bardziej niż osoby dorosłe, są skłonni ulegać różnym pokusom życia codziennego, z uwagi na ciekawość nowych doznań, nastawienie na odkrywanie tego, co zakazane, oraz zaspokajanie ciekawości poznawczej. Stąd też częściej nie liczą się ze swoim bezpieczeństwem, co manifestuje się większą skłonnością do brawurowej jazdy samochodem, sięganiem po alkohol i papierosy czy spędzaniem znacznej ilości czasu przed komputerem [15]. Badania przeprowadzone przez Zalewską-Puchałę i wsp. [16] na grupie 105 studentów wskazują, że 70\% ankietowanych przyznaje się do zapinania pasów bezpieczeństwa podczas jazdy samochodem, ale tylko 47\% respondentów zakład kask ochronny podczas jazdy na rolkach czy rowerze. Jak wskazują badania Randak-Jeziorskiej [17], studenci płci męskiej częściej nie zapinają pasów bezpieczeństwa podczas jazdy samochodem. Natomiast w badaniach Kosteckiej [18], przeprowadzonych w grupie 2465 studentów, wykazano, że osoby z nieprawidłowym BMI istotnie częściej spędzały więcej czasu przed komputerem. Badania własne nie potwierdzają wyżej opisywanych wyników. Wśród ankietowanych studentów najwyżej ocenianym pozytywnym zachowaniem zdrowotnym było zachowanie bezpieczeństwa. Natomiast czynnikami determinującymi ocenę $\mathrm{w}$ tej subskali okazały się wiek oraz występowanie choroby nowotworowej w rodzinie. Subskala oceniała takie zachowania, jak: zapinanie pasów bezpieczeństwa podczas jazdy samochodem, używanie kasku podczas jazdy rowerem, przestrzeganie przepisów ruchu drogowego, zachowywanie bezpieczeństwa nad wodą oraz przestrzeganie przepisów bezpieczeństwa podczas korzystania z urządzeń elektrycznych, mechanicznych, używania substancji chemicznych oraz podczas zabawy fajerwerkami.

W społeczności nadal brakuje świadomości na temat znaczenia snu w życiu człowieka oraz konsekwencji wynikających z braku jego dostatecznej ilości [19]. Sen i zdrowie psychiczne są ze sobą blisko związane. Zbyt mała ilość snu może wywołać wiele problemów ze zdrowiem fizycznym. Ludzie lekceważą to zagadnienie, co doprowadzić może do utraty zdrowia, a nawet przedwczesnej śmierci z powodu niezdiagnozowanych i nieleczonych zaburzeń sennych [20]. W badaniach własnych pozytywne zachowania zdrowotne w zakresie snu, odpoczynku i zdrowia psychicznego znalazły się na drugim miejscu. Wyniki badań przeprowadzone przez Górską-Kłęk i wsp. [21] wśród 185 studentów wykazały, że większość badanych śpi 6-8 godzin na dobę, a ponad połowa śpi w ciągu dnia. Natomiast badanie Błońskiej i wsp. [22] przeprowadzone na 600 studentach wykazało, że $48 \%$ ankietowanych miało problem z zasypianiem, a $61 \%$ respondentów przyznało, że sen nie przynosi im odpoczynku. Białkowska i wsp. [23] przeprowadziły badania na temat zdrowia psychicznego wśród 298 studentów (194 kobiet i 104 mężczyzn), 
women and 104 men) using the Abbreviated Patient Health Questionnaire. The research results indicate that as many as $76.7 \%$ of students reported difficulties with sleeping, whereas in the last two weeks preceding the research, $21.1 \%$ of women and $16.3 \%$ of men reported the feeling of shame, lack of self-confidence and pessimism for at least 7 days in the analysed period. Additionally, $12.4 \%$ of the respondents showed symptoms of depression.

Physical activity is an important part of a healthy lifestyle. At present, a trend of reduced physical activity can be observed among children and youth [24]. Regular physical effort exerts a positive effect on the human body, among others, on the respiratory, circulatory, endocrine, musculoskeletal systems, as well as has a positive influence on mental health [25]. In our study, positive health behaviours in terms of physical activity were ranked fourth in the general order of rating, while the variables determining the rating in this subscale were: age, place of residence during studies, major, family history of cancer and self-assessment of health condition by the respondents. The research conducted by Sochocka et al. [14], involving 553 medical (319) and non-medical (234) students, indicate that more than half of the respondents do not engage in physical activity, and gender and major are variables that have a significant impact on both the type of activity undertaken and the reasons for undertaking it.

Another domain in the hierarchy of ratings among the respondents was the "Body care" subscale that covers prophylactic behaviours concerning following health recommendations, e. g. dressing adequately to the weather, daily tooth brushing, performing preventive examinations and obtaining information on health and disease. In our study, all the analysed variables affected the rating for this subscale. In their research, Majda et al. [26] evaluated the state of oral hygiene and dental health behaviours in a group of 202 medical students. The results of their research showed that more than one third of the respondents used dental services 1 in 6 months, $31.2 \%$ - once a year, $14.4 \%$ - once every two years and $5.9 \%$ - only in the case of pain. In Kleszczewska's et al. $[27,28]$ study, only a small percentage of students regularly attended preventive laboratory tests for ischaemic heart disease or diabetes.

In our study, the lowest-rated subscale for positive health behaviours was "Diet". The human diet is conditioned by many factors; in our own research such factors included age, major and self-assessment of health condition by the respondents. Our own results correspond to the results obtained in a group of 104 students, who in the rating for diet, using a score-based evaluation of dietary habits by Starzyńska, scored a sufficient rating. A similar conclusion in their research was reached by Walentukiewicz et al. [30].

Undertaking studies starts a new stage in the life of a young man. In the context of behaviours related to health, it is a stage of solidifying positive habits and attitudes towards health. However, it can also be a stage of changing health behaviours learned at the family stosując Skrócony Kwestionariusz Zdrowia Pacjenta. Wyniki badań wskazują, że aż 76,7\% studentów zgłaszało trudności ze snem, natomiast w ciągu ostatnich dwóch tygodni poprzedzających badanie $21,1 \%$ kobiet i 16,3\% mężczyzn przez co najmniej 7 dni w analizowanym okresie relacjonowało poczucie wstydu, braku pewności i wiary w siebie oraz pesymizm. Natomiast u $12,4 \%$ badanych stwierdzono objawy depresyjne.

Aktywność fizyczna to ważny element zdrowego stylu życia. Obecnie można zauważyć wśród dzieci i młodzieży trend do obniżenia sprawności fizycznej [24]. Systematyczne podejmowanie wysiłku fizycznego pozytywnie wpływa na organizm człowieka, m.in. na układ oddechowy, krążenia, hormonalny, mięśniowo-szkieletowy, oraz zdrowie psychiczne [25]. Pozytywne zachowania zdrowotne w zakresie aktywności fizycznej w badaniach własnych znalazły się na czwartej pozycji pod względem ogólnej oceny, natomiast zmiennymi determinującymi okazały się wiek, miejsce zamieszkania podczas studiów, kierunek studiów, występowanie choroby nowotworowej $\mathrm{w}$ rodzinie oraz samoocena stanu zdrowia respondentów. Badania przeprowadzone przez Sochocką i wsp. [14] wśród 553 studentów kierunków medycznych (319 osób) i niemedycznych (234 osób) wskazują, że ponad połowa ankietowanych nie podejmuje aktywności fizycznej, a płeć i kierunek studiów są zmiennymi, które mają istotny wpływ zarówno na rodzaj podejmowanej aktywności, jak i przyczyny jej podejmowania.

Kolejne miejsce w hierarchii ocen zajęła subskala „Dbałość o ciało”, która obejmuje zachowania profilaktyczne dotyczące przestrzegania zaleceń zdrowotnych, np. ubieranie się adekwatnie do pogody, codzienne mycie zębów, wykonywanie badań profilaktycznych oraz uzyskiwanie informacji na temat zdrowia i choroby. W badaniach własnych wszystkie analizowane zmienne wpływały na ocenę w tej subskali. Majda i wsp. [26] w swoich analizach oceniali stan higieny jamy ustnej i stomatologiczne zachowania zdrowotne w grupie 202 studentów kierunków medycznych. Wyniki ich badań wykazały, że ponad jedna trzecia badanych korzystała z usług stomatologicznych raz na 6 miesięcy, 31,2\% jeden raz w roku, $14,4 \%$ jeden raz na dwa lata, a 5,9\% tylko w razie bólu. Natomiast w badaniach Kleszczewskiej i wsp. [27,28] niewielki odsetek studentów regularnie wykonywał profilaktyczne badania laboratoryjne z zakresu choroby niedokrwiennej serca czy cukrzycy. W badaniach własnych najniżej ocenianą subskalą pozytywnych zachowań zdrowotnych było "Żywienie”. Sposób żywienia człowieka uwarunkowany jest wieloma czynnikami, przy czym w badaniach własnych były to: wiek, kierunek studiów oraz samoocena stanu zdrowia respondentów. Wyniki własne korespondują $\mathrm{z}$ badaniami przeprowadzonymi $\mathrm{w}$ grupie 104 studentów, którzy oceniając ten parametr za pomocą punktowej skali żywienia wg Starzyńskiej, uzyskali ocenę dostateczną [29]. Podobnie rezultaty osiągnęli Walentukiewicz i wsp. [30].

Podjęcie studiów rozpoczyna nowy okres w życiu młodego człowieka. W kontekście zachowań związa- 
home or a stage of changing anti-healthy behaviours to pro-healthy ones. The evaluation of pro- and anti-healthy behaviours of students aims to recognise health-promoting behaviours and strengthen them. On the other hand, the behaviours that are considered risk factors in the health education process, at the last stage of education, with the contribution of university teachers, by means of health education shall be changed so that a young man, upon leaving te university, was equipped with pro-healthy knowledge and behaviours.

Our study has a few limitations. Firstly, the study was cross-sectional, hence no causal conclusions can be drawn from it. Secondly, the fact that it was carried out in two cities in eastern Poland was a significant limitation as well. Thirdly, the surveyed students do not constitute a representative group of all young males, neither according to the age or the level of education. Despite the above-mentioned limitations, which may influence the level of generalisation of the results, we believe that our discoveries may be considered a base for multicentred studies in the future and that they constitute a valuable support for projecting interventions in the scope of health promotion, directed to male students.

\section{CONCLUSIONS}

1. The ranking of positive health behaviours among male students of universities from the Lublin region is as follows: "Ensuring safety", "Sleep, rest and mental health", "Physical activity", "Body care" and "Diet".

2. In all the categories except for "Sleep, rest and mental health," there is a correlation between older respondents and better parameters for positive health behaviours.

3. Students from non-medical majors attained a higher rating for positive health behaviours in such subscales as: "Diet", "Body care", "Sleep, rest and mental health" and "Physical activity" when compared to those studying medical majors.

4. The studies show that students who rate their health status as poor or average are given a higher rating for positive health behaviours in the following subscales: "Diet", "Body care", "Sleep, rest and mental health" and "Physical activity" when compared to those who rated their health state as good or very good.

\section{Conflict of interest}

The authors declare no conflict of interest.

\section{Author's contribution}

Study design - G.J. Nowicki, B. Ślusarska

Data collection - G.J. Nowicki, Ł. Musur

Data interpretation - G.J. Nowicki, Ł. Musur

Statistical analysis - G.J. Nowicki, Ł. Musur

Manuscript preparation - G.J. Nowicki, A.B. Bartoszek, K.H. Kocka

Literature research - Z.C. Szadowska-Szlachetka, M. Łuczyk nych ze zdrowiem jest to etap utrwalania pozytywnych nawyków i postaw wobec zdrowia, ale może być to również etap zmiany pozytywnych zachowań zdrowotnych wyniesionych $\mathrm{z}$ domu rodzinnego bądź też zmiany zachowań antyzdrowotnych na prozdrowotne. Ocena pro- i antyzdrowotnych zachowań studentów ma na celu rozpoznanie zachowań sprzyjających zdrowiu i ich wzmacnianie. Natomiast te zachowania, które stanowią czynniki ryzyka w procesie edukacji zdrowotnej, powinny być na ostatnim etapie kształcenia, przy współudziale nauczycieli akademickich (poprzez edukację zdrowotną) zmienione, tak aby młody człowiek, opuszczając mury uczelni, był wyposażony w wiedzę i zachowania sprzyjające zdrowiu.

Nasze badanie ma kilka ograniczeń. Przede wszystkim miało charakter przekrojowy, dlatego nie można wyciągnąć na jego podstawie przyczynowych wniosków. Zostało przeprowadzone na terenie dwóch miast we wschodniej Polsce, a badani studenci nie stanowią reprezentatywnej grupy dla ogółu młodych, dorosłych mężczyzn, ze względu na wiek oraz poziom wykształcenia. Pomimo powyższych ograniczeń, które mogą wpływać na poziom uogólnienia wyników, autorzy uważają, że uzyskane wyniki mogą stanowić podstawę do wieloośrodkowych badań $\mathrm{w}$ przyszłości oraz być cennym wsparciem w projektowaniu interwencji z zakresu promocji zdrowia skierowanych do młodzieży akademickiej płci męskiej.

\section{WNIOSKI}

1. Ranking pozytywnych zachowań zdrowotnych wśród studentów płci męskiej lubelskich uczelni kształtuje się następująco: „Zachowanie bezpieczeństwa”, „Sen, odpoczynek i zdrowie psychiczne”, „Aktywność fizyczna”, „Dbałość o ciało” oraz „Żywienie".

2. Wyższy wiek badanych koreluje z lepszymi parametrami pozytywnych zachowań zdrowotnych we wszystkich kategoriach oprócz „Sen, odpoczynek i zdrowie psychiczne".

3. Studenci z kierunków niemedycznych uzyskują wyższą ocenę $\mathrm{w}$ zakresie pozytywnych zachowań zdrowotnych w podskalach: „Żywienie”, „Dbałość o ciało", „Sen, odpoczynek i zdrowie psychiczne” oraz „Aktywność fizyczna” w porównaniu z ankietowanymi studiującymi kierunki medyczne.

4. Badani studenci, którzy oceniają swój stan zdrowia jako zły i średni, uzyskują wyższą ocenę w następujących subskalach pozytywnych zachowań zdrowotnych: „Żywienie”, „Dbałość o ciało”, „Sen, odpoczynek i zdrowie psychiczne” oraz „Aktywność fizyczna", w porównaniu z osobami, które swój stan zdrowia oceniły jako dobry i bardzo dobry.

\section{Konflikt interesów}

Autorzy zgodnie zapewniają o braku konfliktu interesów. 


\section{REFERENCES}

1. Woynarowska B. Jak tworzymy szkołę promującą zdrowie. Instytut Matki i Dziecka, Warszawa 1995.

2. Wojciechowska K. Nauczyciel przewodnikiem w procesie promowania zdrowia w szkole. Roczniki Pedagogiczne 2014; 6(42): 127-141.

3. Krzych Ł. Analiza stylu życia studentów Śląskiej Akademii Medycznej. Zdr. Publ. 2004; 114(1): 67-70.

4. Karski J.B. Praktyka i teoria promocji zdrowia. CeDeWu. Warszawa 2003.

5. Gorbaniuk J., Chuchra A. Preferencje żywieniowe kobiet i mężczyzn aktywnych zawodowo. Roczniki Teologiczne 2017; 64(10): 159-172.

6. Łaszek M., Nowacka E., Szatko F. Negatywne wzorce zachowań studentów. Część I. Konsumpcja alkoholu i stosowanie substancji psychoaktywnych. Probl. Hig. Epidemiol. 2011; 92(1): 114-119.

7. Polak M., Stokwiszewski J., Waśniowska A., Piotrowski W., Zdrojewski T., Drygas W., Wojtyniak B., Jankowski P., Pająk A. Ocena ryzyka sercowo-naczyniowego za pomoca funkcji SCORE w odniesieniu do ryzyka określonego na podstawie umieralności z powodu chorób układu krążenia w Polsce. Zdr. Publ. Zarz. 2015; 13(4): 328-336, doi: 10.4467/20842627OZ.15.034.5461.

8. Królikowska S. Nierówności w stanie zdrowia między kobietami a mężczyznami w kontekście płci biologicznej oraz społeczno-kulturowej. Acta Universitatis Lodziensis. Folia Sociologica. 2011; 39: 33-52.

9. Cienciara D. Płeć kulturowa jako determinant zdrowia mężczyzn. Zdr. Publ. Zarz. 2015; 13(4): 347-359, do: 10.4467/20842627OZ.15.036.5463.

10. Dobson A. J. An Introduction to Generalized Linear Models. Chapman and Hall, London, New York 1990.

11. Woynarowska-Sołdan M., Węziak-Białowolska D. Analiza psychometryczna Skali Pozytywnych Zachowań Zdrowotnych dla dorosłych. Probl. Hig. Epidemiol. 2012; 93(2): 369-376.

12. Gronowska-Senger A. Żywienie, styl życia a zdrowie Polaków. Żyw. Człow. Metab. 2007; 34(1/2): 12-21.

13. Kubińska Z., Bergier B. Dbałość o zdrowie w opinii studentów wychowania fizycznego i zdrowia publicznego z uczelni w Białej Podlaskiej. Med. Og. Nauk Zdr. 2013; 19(3): 251-254.

14. Sochocka L., Wojtyłko A. Aktywność fizyczna studentów studiów stacjonarnych kierunków medycznych i niemedycznych. Med. Śr. 2013; 16(2) 53-58.

15. Baran A., Stocka A. Kierunek studiów jako wyznacznik zachowań zdrowotnych. Prz. Med. Uniw. Rzesz. Inst. Leków 2008; 4: 326-331.

16. Zalewska-Puchała J., Majda A., Korzonek R. Zachowania zdrowotne i poczucie własnej skuteczności studentów w utrzymaniu zdrowia. Probl. Pielęg. 2013; 21(4): 504-511.

17. Randak-Jezierska M. Świadomość, odpowiedzialność, dostrzeganie wzajemnych powiązań jako gwarancja bezpieczeństwa na drodze dla kierowcy i jego pasażerów. Logika-Nauka 2011; 3: 2275-2290.

18. Kostecka A. Niektóre zachowania zdrowotne studentów a ich masa ciała. Medical and Biological Sciences 2007; 21(3): 53-58.

19. Sykut A., Ślusarska B., Jędrzejkiewicz B., Nowicki G. Zaburzenia snu jako powszechny problem społeczny - wybrane uwarunkowania i konsekwencje zdrowotne. Pielęg. XXI w. 2017; 16(2): 53-57, do: 10.1515/ pielxxiw-2017-0019.

20. Kapała A. Zaburzenia snu w kontekście przemian cywilizacyjnych. Sztuka Leczenia 2014; 29(3-4): 35-44.

21. Górska-Kłęk L., Mełeszko K, Boerner E. Prozdrowotne elementy stylu życia studentów Akademii Wychowania Fizycznego i Uniwersytetu Ekonomicznego. Acta Bio-Optica et Informatica Medica 2011; 17(4): 268-270.

22. Błońska B.K., Gotlib J. Wystepepowanie zaburzeń snu wśród studentów. Prz. Med. Uniw. Rzesz. Inst. Leków 2012; 4: 485-497.

23. Białkowska J., Mroczkowska D., Zomkowska E., Rakowska A. Ocena zdrowia psychicznego studentów na podstawie Skróconego Kwestionariusza Zdrowia Pacjenta. Hygeia Public Health 2014; 49(2): 365-369.

24. Dębski M. Stan aktywności fizycznej studentów. Pol. Prz. Nauk Zdr. 2014; 2(39): $138-142$

25. Siwiński W., Rasińska R. Aktywność fizyczna jako zasadniczy cel stylu życia i zdrowia człowieka. Pielęg. Pol. 2015; 2(56): 181-188.

26. Majda A., Zalewska-Puchała J., Bodys-Cupak I., Czubak-Lewandowska E. Stan higieny jamy ustnej i stomatologiczne zachowania zdrowotne studentów kierunków medycznych. Probl. Hig. Epidemiol. 2014; 95(4): 895-900. 27. Kleszczewska E., Kleszczewski T., Łogwiniuk K., Szpakow A., Boyko O. Stosunek do badań profilaktycznych studentów z wybranych uczelni wyższych z Suwałk, Grodna i Lwowa. Cześć I. Choroba niedokrwienna serca. Hygeia Public Health. 2014; 49(3): 458-465.

28. Kleszczewska E., Kleszczewski T., Łogwiniuk K., Szpakow A., Boyko O. Stosunek do badań profilaktycznych studentów z wybranych uczelni wyższych z Suwałk, Grodna i Lwowa. Część II. Cukrzyca a zdrowy styl życia. Hygeia Public Health. 2014; 49(3): 466-471.

29. Piasecka H., Ślusarska B., Nowicki G. Zdrowie jako wartość wśród młodzieży studenckiej w uwarunkowaniach społeczno-demograficznych i ocena żywienia badanej grupy. Pielęg. Pol. 2015; 2(56): 127-134.

30. Walentukiewicz A., Łysak A., Wilk B. Ocena sposobu żywienia studentów w kontekście profilaktyki chorób cywilizacyjnych. Probl. Hig. Epidemiol. 2014; 95(3): 772-777. 